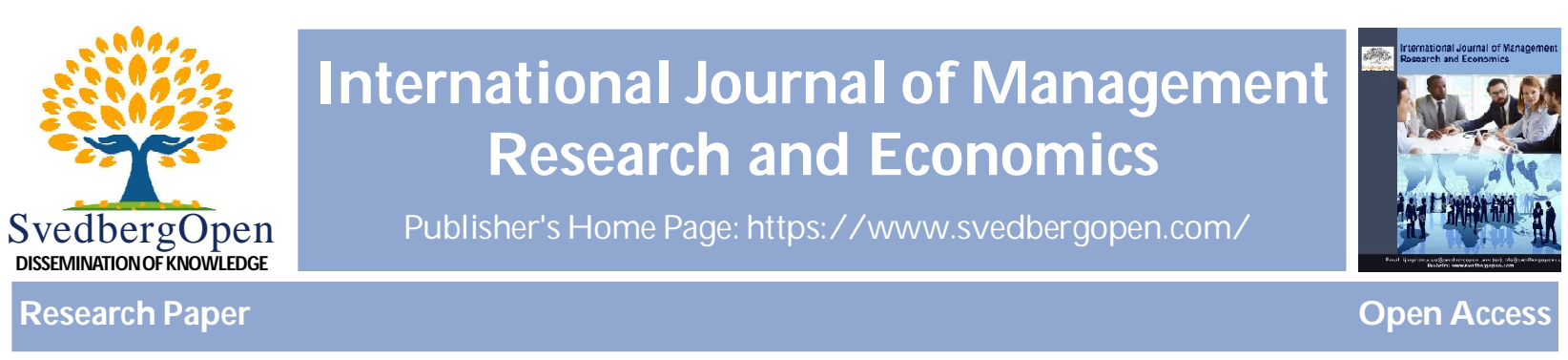

\title{
The accounting nature of money and claims
}

Maxime Izoulet ${ }^{{ }^{*}}$

${ }^{1}$ Doctor of Economics, Researcher at CEMI-CRS, Paris, Accounting Officer at Lycée Théodore de Banville, Moulins, France.

E-mail: maxime.izoulet@gmail.com

Article Info

Volume 1, Issue 2, April 2021

Received : 12 January 2021

Accepted : 19 March 2021

Published : 05 April 2021

doi: 10.51483/IJMRE.1.2.2021.10-17

\begin{abstract}
This paper uses the logic of double-entry bookkeeping, as it is universally used in the economic life of banks, central banks and companies, to precisely define the nature of claims and money. First, it shows that these two forms of value are always distinct in accounting, but that the claim is by nature unstable, ambivalent, and can evolve towards the monetary form under certain conditions. Then, in a second step, we show that the claim has three sources in return for which it is issued: the loan by money creation, the loan of existing money, and the forward sale of goods. These accounting relationships, which are in fact a definition of book value, then allow us to sketch out an analysis of contemporary financial and monetary crises and how to respond to them effectively.
\end{abstract}

Keywords: Accounting, Monetary theory, Money, Claims, Debt, Credit, History of money

(C) 2021 International Journal of Management Research and Economics. This is an open access article under the CC BY license (https://creativecommons.org/licenses/by/4.0/), which permits unrestricted use, distribution, and reproduction in any medium, provided you give appropriate credit to the original author(s) and the source, provide a link to the Creative Commons license, and indicate if changes were made.

\section{Introduction}

Modern credit money was born of claims, promises of payment which, by circulating between different agents as a means of payment ${ }^{1}$, and then by being recognized by the state, gradually became a currency in its own right ${ }^{2}$. The invention of double-entry bookkeeping in the Middle Ages, by automating the management of these claims and linking them closely to the concept of profit ${ }^{3}$, allowed for their massive expansion and their gradual transformation into a new form of money: the credit money we use today.

In this paper, we will try to define precisely what distinguishes a receivable from money in accounting and what makes it similar. We will see that while the two are always distinct, the claim has an ambivalent nature that can make it evolve into a monetary, or quasi-monetary, form if it starts to circulate. Then, in a second step, we will detail the three accounting operations that can be the source of the issuance of a claim and we will draw from them more general analyses of the functioning of modern financial markets.

1 De Roover R. (1948). Money, Banking and Credit in Mediaeval Bruges - Italian Merchant Bankers, Lombards and Money Changers - A Study in the Origins of Banking, The mediavael academy of Academy, Cambridge, Massachusetts.

2 Schumpeter, J.A. (1954). Histoire de l'analyse économique, tome 1: L'âge des fondateurs, Tel Gallimard.

3 Fourastié, J. (1944). Comptabilité générale conforme au plan comptable général, librairie générale de droit et de jurisprudence, Paris.

\footnotetext{
* Corresponding author: Maxime Izoulet, Doctor of Economics, Researcher at CEMI-CRS, Paris, Accounting Officer at Lycée Théodore de Banville, Moulins, France.E-mail: maxime.izoulet@gmail.com
} 


\section{The monetary potential of claims}

But if credit money is the result of what constituted claims in past centuries, it should be noted as a preamble that the old money itself was born of a system of claims. ${ }^{4}$ It probably appeared as an accounting tool to manage barter in the temple, as many archaeological sources and the most recent anthropological works attest. ${ }^{5}$ The first traces of human writing are also accounting documents. ${ }^{6}$ Originally, money was already a claim, but this claim was a promise to deliver a good to the temple. However, such a promise, recognized by a scribe of the time as credible, immediately became a value for the one who made it. For in exchange for it, he could obtain a real commodity, although he was then subject to a debt. This recognition of a claim as a value, implying at the same time the existence of a debt, is the origin of money and David Graeber has shown it well. Whether it is notified in an accounting document, or materialized by a written document, which is a claim for the one to whom something is owed or a debt for the one who owes, the promise becomes a value. And, from the moment that this value circulates between different agents, which occurs at the moment when it is accounted for in a standardized way, this value acquires the quality of money. ${ }^{7}$ The last stage in this process is the institutional recognition of this money, its legal and social recognition, which makes it a currency in the full sense of the term.

This origin of money is now well documented, although its link with the commodities that served as its concrete support, such as precious metals and especially gold, seems not to have been fully clarified. But this paper is not specifically concerned with this question, nor with the origins of this ancient currency, as it was used in most human civilizations from Mesopotamia onwards. It is simply useful to observe that money has from the outset been closely linked to claims, i.e., the commitment to deliver a value.

From the time of the invention of money, which can be dated at least to the time of the appearance of writing itself, until the end of the Middle Ages in Italy, it has not undergone any major conceptual transformation. As David Graeber has shown, credit currencies were often the prerogative of merchant civilizations, while the great territorial states of antiquity, of which the Roman Empire is the archetype, tended to destroy these systems in order to impose systems of metallic currencies, in which circulation was reduced to a back-and-forth between state budgetary expenditures and the levying of taxes. The monetary needs of these states were then entirely dependent on the extraction of the precious metals with which their currencies were identified. ${ }^{8}$

Even from this metallic currency, there have always existed credit systems. In other words, there have always been debts issued with this metallic currency itself. These claims, typically, could be made on the occasion of a loan. The borrower then received money and gave a promise of future payment. The borrower then had a debt, and the lender a claim. This loan could itself be divided into two cases. The loan by mobilization of existing money, which could be made by any saver as long as the law allowed it, and the loan by money creation, which could be made only by the institution managing the money.

This claim could also be issued on the basis of a payment term. In this case the borrower received a commodity and gave a promise of money. In the same way, a promise of money was issued, which represented a debt for the borrower and a claim for the lender.

This promise of payment was indeed a promise of money, and not a promise of a commodity as in the remote times of the origin of money.

It was therefore a value, but a value different from money, a value that is issued from money, but that cannot be assimilated to it, a potential value, not a value in itself. For money is a definitive means of payment, liberating, whereas the claim is linked to the realization of a promise. It may not be honored, in which case it is a value that disappears. On the contrary, money is a value in itself, which can eventually be depreciated, but which cannot disappear.

There is thus a fundamental difference between money and claims, as this paper attempts to expose. However, we have seen that money was originally a promise of a commodity, so we could deduce that any claim is money. But this would be to deny the fact that the claim does not have the same legal status. It is not recognized as money by the

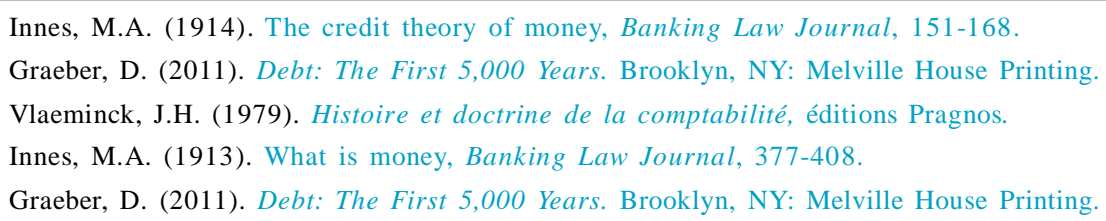


institution that regulates that money. If the claim begins to circulate anonymously among agents, it may take on the appearance of money, but this still does not give it the official recognition that makes it a liberating means of payment.

This means that the claim is a potential currency, or a currency in gestation, but not a currency as such. If it circulates between agents, it becomes a quasi-money, but without liberatory power. If it is recognized and guaranteed by the State, it becomes a currency in its own right, but it is then a new currency. In this case, it circulates in parallel to the initial currency, with which it can be converted according to an exchange rate.

These fundamental characteristics and relations between money and claims are summarized in the diagram (Figure 1).

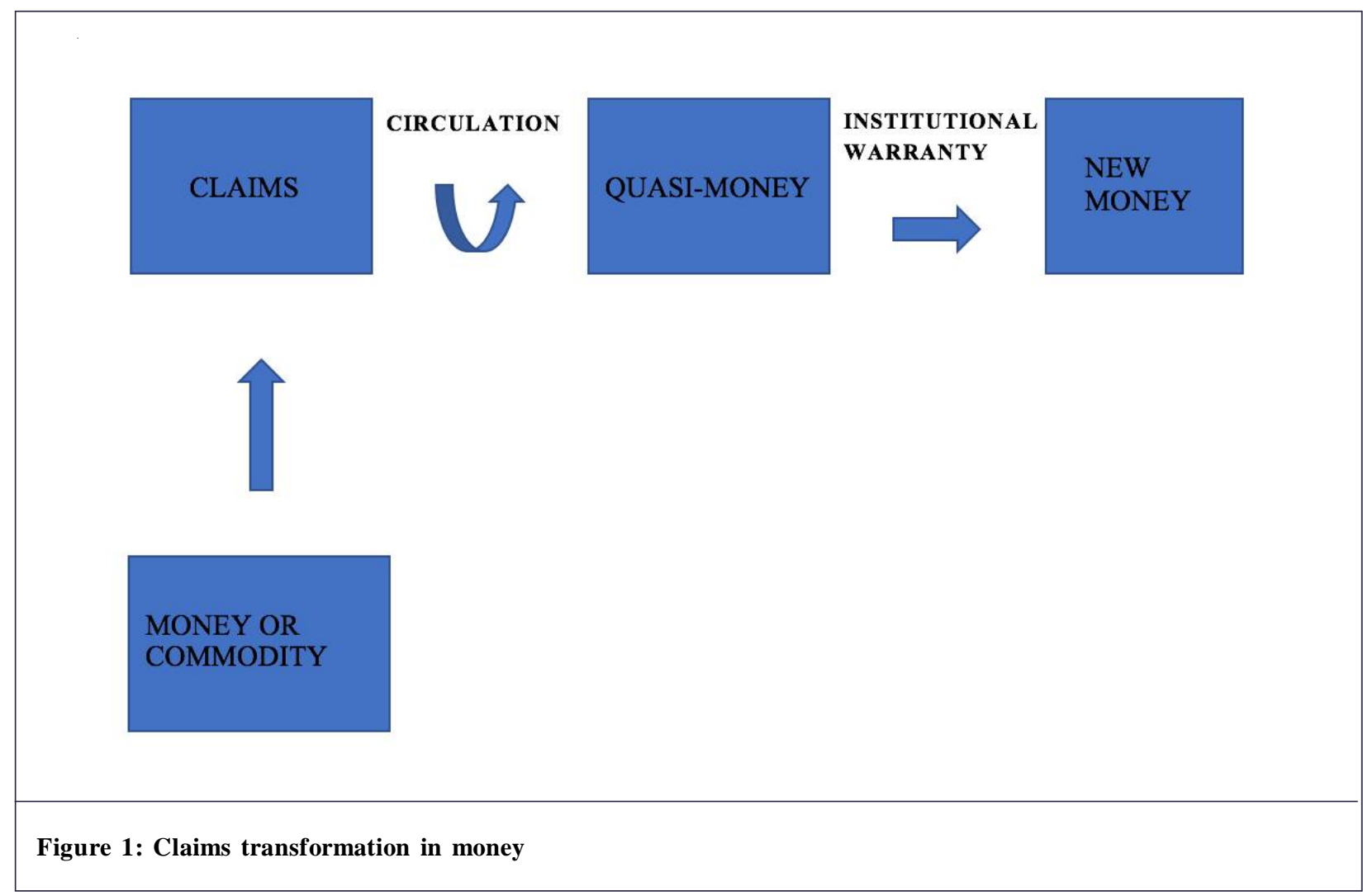

This monetary potential of the claim played an important role in the ancient civilizations, since many of these civilizations developed advanced credit systems around this characteristic, in contrast to the large territorial states that used metallic currencies.

But a decisive break occurred in Italy around the $13^{\text {th }}$ and $14^{\text {th }}$ centuries. At that time, the claims began to develop in proportions unknown until then. The written documents that materialized them, the bills of exchange or orders of payment, exploded ${ }^{9}$, and the accounting management of these claims underwent a phenomenal expansion, which only became stronger later on. ${ }^{10}$ This rupture was the consequence of two closely related facts: the reinforcement of the Church's ban on interest-bearing loans and, in response to this ban, the invention of double-entry bookkeeping. As this paper attempts to demonstrate, it is this new technique that allowed the enormous development of claims, because these claims were the only way to develop credit at a time when trade was growing (especially from the $12^{\text {th }}$ century in Italy).

The essential contribution of double-entry bookkeeping in the management of these claims was a reliable technique, allowing easy verification, and linking the claims to a new concept, the definition of which is specific to the double entry: profit. Double-entry bookkeeping makes it possible to link receivables to profit in an automatic technique. Indeed, it is not necessary to understand the meaning of the double entry to use it, and this is what makes it so effective in practice. From then on, the use of double-entry bookkeeping could be generalized very easily because it was practical to use, and the deep links between profit and receivables appeared of their own accord, with time and the expansion of the doubleentry logic, without anyone, including the designers of this technique, ever having consciously programmed anything.

9 Heers, J. (2012). La naissance du capitalisme au Moyen Age, changeurs, usuriers et grands financiers, Perrin éditions.

10 De Roover,R. (1956). L'évolution de la lettre de change, XIVe - XVIII e siècle, Affaires et gens d'affaires, éditions Armand Collin. 
What were these links? Those of capitalism itself, that is, the joint expansion of profit and credit.

From the invention of double-entry bookkeeping in the thirteenth and $14^{\text {th }}$ centuries onwards, claims underwent a phenomenal expansion thanks to merchant-bankers, then to bankers, and finally to public banks, commercial companies and the States themselves. Slowly but surely, they began to acquire the character of a credit currency. At first, they circulated between the various actors, notably in the great European fairs whose expansion closely followed that of capitalism. Then, faced with crises of confidence, in other words financial crises, that waves of non-repayment of these claims could provoke, and in their wake the bankruptcy of the banks that circulated them, the states began to secure their value, to institutionalize them, by creating public banks for this purpose ${ }^{11}$. This process was long and difficult, and in fact corresponds to the process of invention of central banks.

The expansion of claims to unprecedented proportions from the end of the Middle Ages allowed their gradual transformation into a credit money, which gradually supplanted the official currency itself. By developing, circulating and gradually becoming institutionalized thanks to the States and central banks, the enormous mass of claims, which the actors of the Renaissance used to call "bills of exchange" and which, with the invention of the bank bill by the Bank of England, more often took the name of "paper money" or "fiduciary money", became itself a currency in its own right, and this credit money is the origin of the credit money that we use today. This is the reason why our money still functions today as a credit system. Indeed, its creation is carried out by private banks on the occasion of the granting of a loan ${ }^{12}$ and this functioning is the heritage and the trace of the fact that originally this money was only a simple credit, that is to say a claim.

To differentiate money from claims, which are potential money, in gestation, that become quasi-money when they circulate between agents, the imperfect term of dimensions of money will be used in this paper. This term seeks to express the fact that money and claims cannot be equated, because one is institutionally recognized, it is a definitive, liberating means of payment, whereas the other is a value in abeyance, which can be cancelled at any moment if the promise is not honored. However, when they circulate, these claims acquire all the practical qualities of a currency and can very well be used as such by economic agents. They can become quasi-money.

Moreover, if the state guarantees them and recognizes them as a liberating means of payment, they can in turn become a currency in their own right. This theoretical distinction between the two forms of value, claims and money, is one of the pillars on which the definition of value introduced by double-entry accounting is based. By using it, this paper seeks to better understand what money is and what finance is.

What, indeed, is modern finance in this scheme? More or less the same as it has been in Europe since the Renaissance, i.e., a mass of claims in circulation. We have noted the profound instability of this very particular form of value, the claim, which is always oscillating between disappearance and transformation into money. It must be emphasized that this instability of the claim is transmitted and explains to a large extent the instability of finance itself.

Certainly, the delay in payment, i.e., the deferred payment of goods, was the privileged instrument for the expansion of claims in the past, leading to the development of our modern credit currency, because it was the only way to circumvent the Church's prohibition of direct interest lending. Today, such a constraint no longer exists, and the payment term is no longer the exclusive instrument for the development of claims on the markets. To create such claims and circulate them on a market, one resorts instead to the classic money loan, whether it is made by money creation with a classic bank, or by mobilization of existing money with a bank or a mutual fund in the case of a bond issue. A bond is a claim, as is a commitment to repay a conventional loan. As varied as these products are, what they have in common is that they are claims. The financial assets circulating in the markets (leaving aside the case of equity markets, which involve property rights) are therefore fundamentally a quasi-money, different from the money itself on which they are based. It is a potential currency, in gestation, which has the qualities and functions of classical money in times of confidence, but which can be subject to a brutal disappearance on the occasion of a financial crisis, i.e., when some of these promises of payment in circulation are not honored. The more they circulate, the more we lose sight of the fact that they are not quite money. Yet, legally, financial assets are not money and are therefore not a liberating or definitive means of payment.

11 Tucci, U. (1981). Il Banco della Piazza di Rialto, première banque publique vénitienne, Cahiers de la Méditerranée, 5(1) 155-169. https://doi.org/10.3406/camed.1981.1552

12 Plihon, D. (2013). La monnaie et ses mécanismes, éditions la Découverte. 
However, as we saw during the last financial crisis of 2008, the value of these financial assets has become too important to let them disappear without taking action ${ }^{13}{ }^{14}$. Given the level of commitment in these assets of a large part of the world economy, letting them disappear during a crisis of confidence would have disastrous effects on the real economy and credit in general ${ }^{15}$, because they would lead to a loss of wealth for all the actors who consider it as a value in itself, as a monetary value. This is why, during this crisis, governments and central banks have tended to guarantee and stabilize the value of these financial assets, which have seen their interest rates fall significantly ${ }^{16}$. If we take the necessary historical perspective, this means that this mass of claims, of financial assets in circulation that can be qualified as quasi-money, is in the process of becoming, by force of events, and even if this movement is in its infancy, a currency in its own right. This is confirmed by the accounting analysis of many banking economists, who clearly show that central banks have transformed many securities (i.e., many claims) held by commercial banks into money in its own right. There is thus a process of transformation of financial market claims into money, which necessarily raises the question of the link that this money supply has with the general price level.

Indeed, as we have seen, a claim becomes quasi-money when it circulates, and then full-fledged money when it is recognized and guaranteed by a central bank. This is precisely what happened with the emergence of modern money, and this is what will certainly happen, no matter how long it takes for this realization to take hold, with the current financial quasi-money, because we are too deeply involved in this process to escape it.

Moreover, quantitative easing is a step in the right direction, albeit imperfectly, certainly unsteadily, towards a guarantee by central banks of the value of financial assets. With quantitative easing, central banks begin to play the role in the financial markets that they once played with modern money, by intervening as the ultimate security, as a guarantee of the financial system itself, and above all by transforming financial securities into official money ${ }^{17}$.

As we can see, the historical dialectic between money and claims is far from over. If it took on its full meaning from the end of the Middle Ages to the $20^{\text {th }}$ century in the gradual emergence of credit money, it continues today to produce great effects with the emergence of contemporary finance, which, by developing rapidly, tends to become itself a currency in its own right, a new currency, whose undeniable link with monetary policy has been emphasized by numerous works ${ }^{18}$.

Finally, this historical process, which begins at the end of the Middle Ages and continues to the present day, and which is that of the historical development of credit money, is profoundly linked to the evolution of capitalism itself, and to the transformation of the techniques of production and of the social relations of power that make it possible.

But it is necessary to establish the three possible sources of the issuance of a claim within the framework of the structure of value fixed by double-entry accounting.

\section{The three sources of the claim}

In order to be clearer in the presentation, we need to detail the different forms of credit on the occasion of which a claim is issued. This diagram is valid in principle for any contemporary or historical transaction, whether it is formal and gives rise to a precise accounting entry, or informal. But it should be noted that the term of payment was the preferred form that allowed for the expansion of credit money in the Middle Ages, since direct loans were prohibited, and their existence, although attested to by historians, was nonetheless strongly limited by the laws of the Church ${ }^{19}$. Conversely, the two forms of lending, by money creation or by mobilization of existing money, are the two most widely used contemporary forms of credit, since they correspond in fact to bank lending and bond issues on a financial market.

For these three types of credit, there is a lender and a borrower. In each case, what the lender gives is not exactly the same thing. It may be either a commodity, existing money, or money created for the occasion. But what the borrower gives in exchange, on the other hand, does not vary; it is always the same thing: a promise to pay, that is, a debt for him and a claim for the lender.

13 Cecchetti, Stephen G. (2008). Crisis and Responses:the Federal Reserve and the Financial Crisis of 2007-2008, NBER Working Paper No. 14134 JEL No. E5.Online : https://www.nber.org/papers/w14134.pdf

14 Cecchetti, Stephen G. (2008). Money, Banking, and Financial Markets, 2nd edition. New York, N.Y. : McGraw Hill - Irwin.

15 Meaning, Jack and Zhu, Feng, (2011) The impact of recent central bank asset purchase programmes. BIS Quarterly Review. Available at SSRN: https://ssrn.com/abstract=1971210

16 Choulet C. (2015). QE and Bank Balance Sheets, the American experience, 2015. note de conjoncture de la BNP-Paribas. Online :https:// economic-research.bnpparibas.com/Views/DisplayPublication.aspx?type =document\&IdPdf=25852\&fbclid=IwAR3LNIUuOxF2R6f7 NChL478UJ6KCeHaVdXLjMSqkPSFMnInalfv4JeO_dtk

17 Ibid.

18 Aglietta, M. and Orléan, A. (1982). La violence de la monnaie, préface de Jacques Attali, économie en liberté, Presses Universitaires de France.

19 Heers (2012). La naissance du capitalisme au Moyen Age. 
Let us try to summarize in a diagram the different forms of credit (Figure 2).

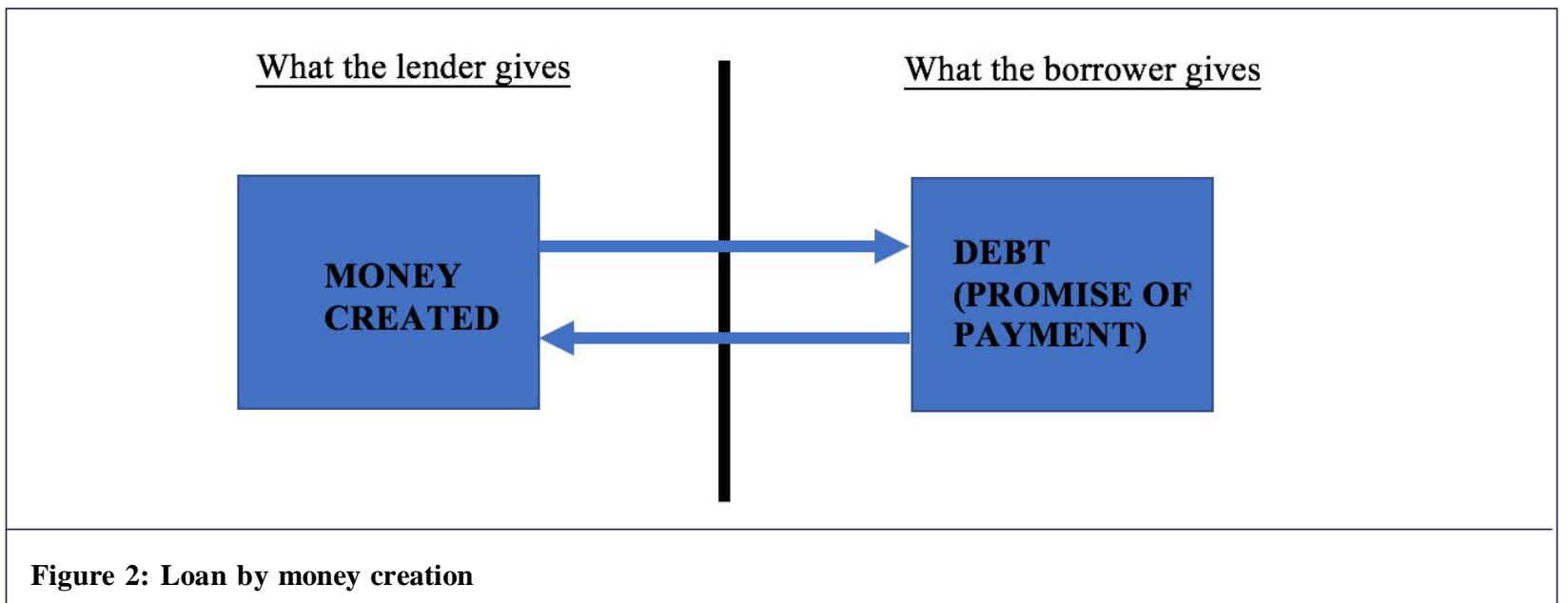

First, there is the interest-bearing loan through monetary creation.

This type of credit is typically the type used by private banks today when they create money. In their accounting, a line is created to fill their client's account, i.e., money is created directly on the client's account. On the other hand, a claim on this customer is created against a third-party account, materializing the customer's debt to the bank, i.e., the bank's claim on the customer ${ }^{20}$. During the life of the credit, the bank's accounting records reflect both the money created for the customer and the claim issued against it ${ }^{21}$. When the credit is repaid, the claim disappears and so does the currency, except for the interest paid to the bank's net banking income, i.e., to its result.

The second type of credit is the loan by mobilization of existing money (Figure 3).

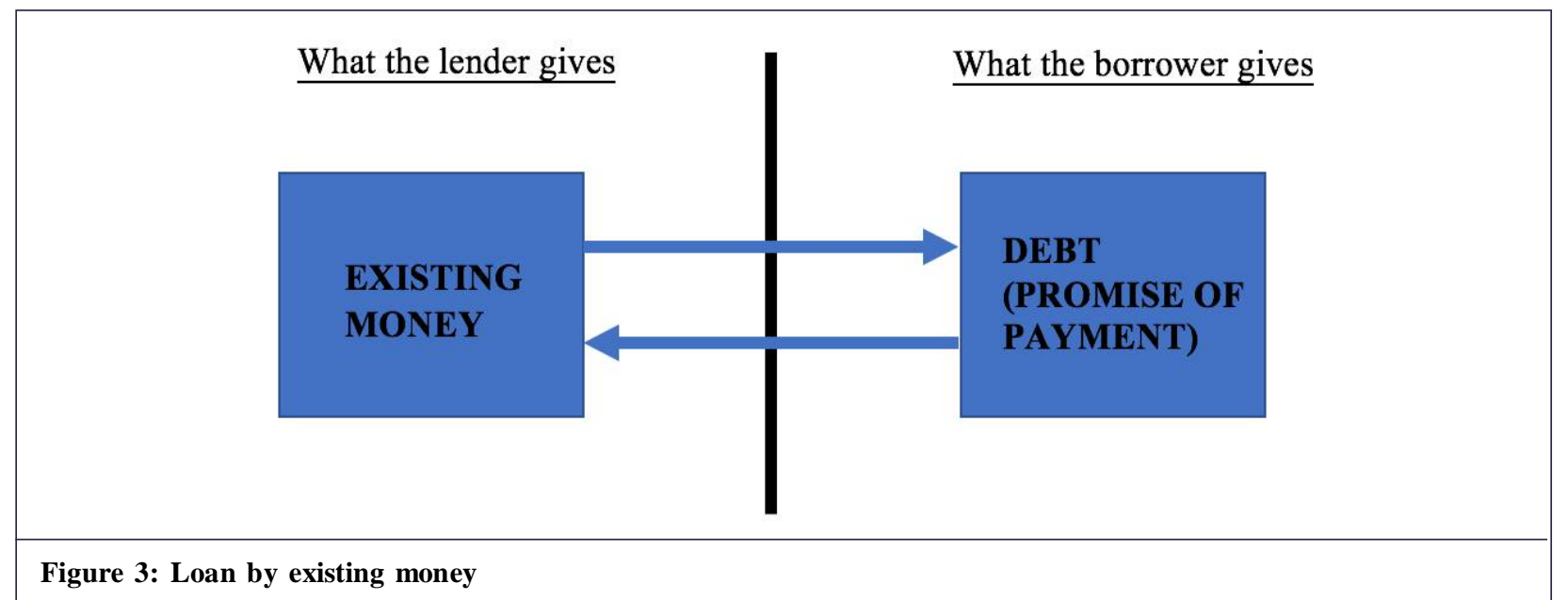

This operation is a credit of the same type as the previous one for the borrower, but the big difference is that the money lent is not created by the lending organization. This is why this type of loan is not reserved for banks, and can be used by any organization. Typically, this involves the issuance and purchase of bonds by investment funds from private companies on a financial market. It should be noted that this transaction actually takes place in the accounting of the clearing house that organizes the market, or in the so-called "off-balance sheet" accounting of the private bank ${ }^{22}$. In either case, money is transferred from the bank or the clearing house to the borrower, and at the same time a claim is issued for one client and a debt for the other, which is the obligation itself, that is, again, the promise of payment.

The last type of credit is the term of payment, or the forward sale of goods (it amounts to the same thing), which was the privileged instrument of the expansion of modern money during the Renaissance, and remains the basic foundation of derivative contracts today (Figure 4).

\footnotetext{
20 Formagne, M. (2015). Introduction à la comptabilité bancaire, 2e édition, RB Editions.

21 Caudal, J.P. (2016). Traité de comptabilité bancaire, doctrine et pratique. 2ème édition, préface de Michel Pébereau, RB édition.

22 Richard H. Timberlake, Jr. (1984), The central banking role of clearinghouse associations, Journal of Money, Credit and Banking, $16(1), 1-15$.
} 


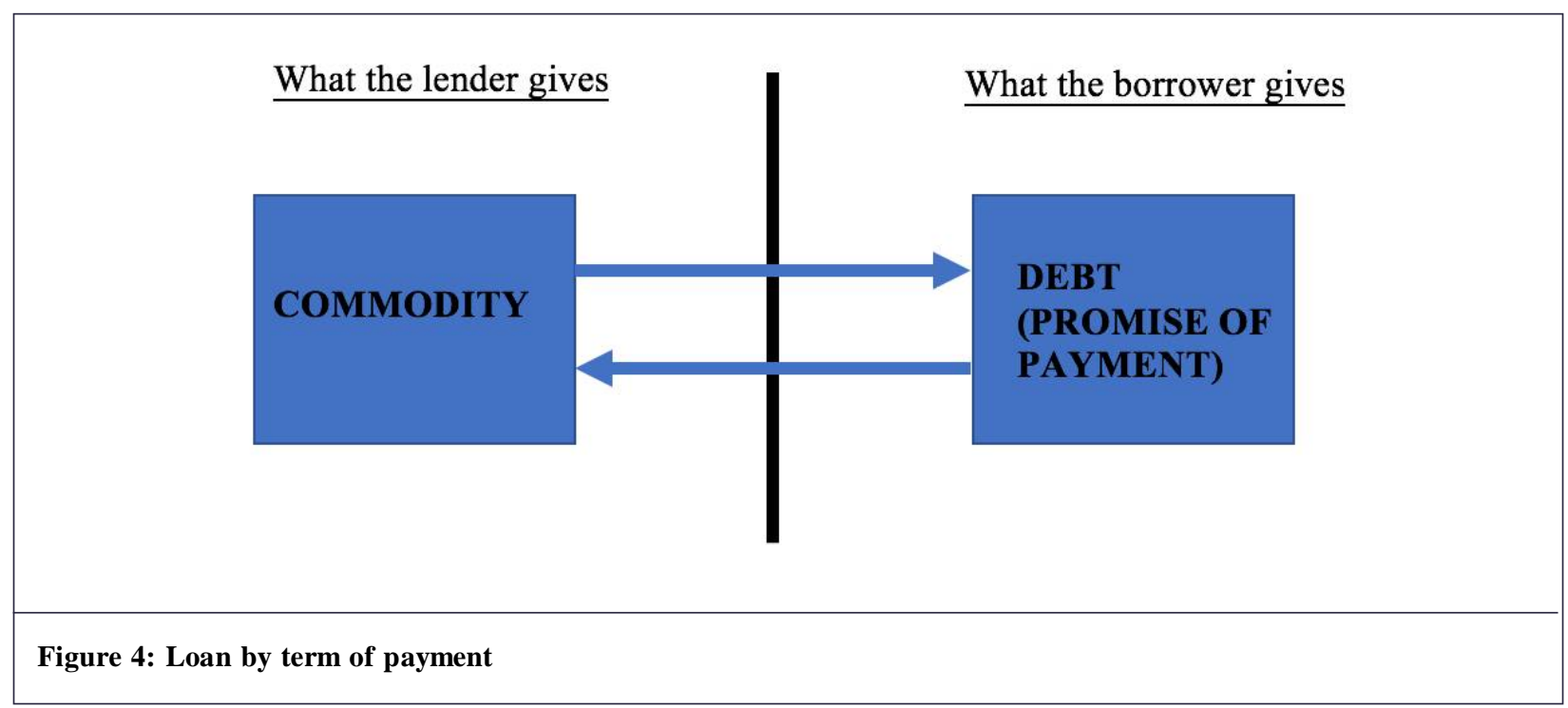

In this case, what is handed over by the lender is directly a good. In return, he receives a promise to pay. In his accounting, the business, or in the Middle Ages the merchant-banker, records the value of his goods on the one hand and a claim on his borrower on the other.

In all three cases, we see that the common point is always that the loan leads to the issue of a promise of money. This promise of money is also a debt for the borrower, and a claim for the lender, and it is this claim, generally materialized by an accounting entry, that can be put into circulation, i.e., transmitted to a third party as a value ${ }^{23}$. Double-entry bookkeeping played a major role in the organization of this circulation and still plays a major role today.

Indeed, it is by circulating and being materialized under the famous name of "bills of exchange", in fact payment orders, that these claims will explode from the Renaissance onwards, and become a credit currency progressively recognized by the States and the central banks, until becoming the contemporary credit currency that we use.

But on the other hand, today, these claims, whether they are issued from loans by money creation or by the issuance of financial securities, are the basis of what we call financial assets. Bonds are promises of money, as are claims on bank credit, and by circulating them in their off-balance sheet accounting, private banks are increasingly using these commitments, these claims, as money, just as all the players in the financial markets do thanks to the clearing houses, which manage this process from an accounting point of view ${ }^{24}$. A large part of modern finance is thus made up of the circulation of claims, and these claims tend to be transformed into quasi-money as they circulate. In this respect, financial crises can be understood as crises of confidence that brutally destroy this new money supply in gestation by putting a momentary end to its circulation, that is, to what makes it quasi-money. The protective action that is then taken by central banks, and in particular quantitative easing, aims to preserve confidence in financial assets, i.e., in this quasi-money. Quantitative easing can therefore be understood as the beginning of an institutional guarantee of this quasi-money by central banks, which then position themselves as the central banks of the new currency. We shall return to this fundamental question in detail, but it should be noted that it was precisely this role of guarantee and institutional recognition of the new credit currency during the Renaissance that led to the emergence of central banks in Western Europe and then throughout the world. ${ }^{25}$ The parallel with the present time is therefore striking.

\section{Conclusion}

This article has thus shown that double-entry accounting allows us to better define money and finance. Indeed, we have uncovered one of the essential elements that define value in accounting: the distinction between debt and money. We then showed that a fundamental aspect of the nature of the claim was its ambivalence and its instability, since under certain conditions of trust, it can evolve towards the monetary form. This specificity is in fact at the basis of the functioning of all finance and its crises.

\footnotetext{
23 De Roover R. (1948). Money, Banking and Credit in Mediaeval Bruges - Italian Merchant Bankers, Lombards and Money Changers - A Study in the Origins of Banking, The mediavael academy of Academy, Cambridge, Massachusetts.

24 Braun, B., and Gabor, D. (2019, March 13). Central banking, shadow banking, and infrastructural power. Available online: https:/ /doi.org/10.31235/osf.io/nf9ms

${ }^{25}$ Tucci, Il banco della Piazza di Rialto, 1982.
} 
We then showed that there are three fundamental accounting operations by which this claim can be issued: the lending of money by money creation, the lending of existing money, and the forward sale of goods. These three operations make it possible to define the entire architecture of contemporary finance and can be well defined thanks to double-entry accounting. Therefore, the logical understanding of this technique and its use seems to be a strategic issue for future research.

\section{References}

Ali al-Fijawi M.F. and Mohd Yunus, S. (2019). Modern Applications of Profit-Sale (Bay Murabahah) from a Maqasid Shari'ah Perspective, Al-Shajarah. Journal of the International Institute of Islamic Thought and Civilization (ISTAC), 24(1), 49-99.

Andreica, I. (2016). Double entry bookkeeping vs single entry bookkeeping. Bulletin of University of Agricultural Sciences and Veterinary Medicine Cluj-Napoca. Horticulture, 73(2), 282-290.

Cochrane, D.T. (2015). What's Love Got to Do with It? Diamonds and the Accumulation of De Beers, 1935-55. Unpublished $\mathrm{PhD}$ Dissertation, Graduate Program in Social and Political Thought, York University.

Daniela, T.G., Marioara, A. and Daniel, A.C. (2014). Accounting Treatments Used for Accounting Services Providers. Annals-Economy Series, 4, 295-302

Dumitru, A., Motoi, A.G. and Curelaru, L. (2016). Basic Accounting in European Projects, Annals of the University of Craiova for Journalism, Communication and Management. (2).

Gleeson White, J. (2013). Double Entry, How the Merchants of Venice Created Modern Finance. Allen and Unwin.

Hoskin, K.W., Ma, D. and Macve, R.H. (2016). Rational Evolution or Socially Constructed Counter-myth? Cross-cultural Perceptions of the Development of Chinese Commercial Accounting up to c.1850 and its Significance. LSE/ University of Birmingham working paper (earlier version at http://www.lse.ac.uk/economicHistory/workingPapers/ 2012/WP160.pdf).

Izoulet, M. (2021). The Accounting Nature of Money and Claims. Available at SSRN: https://ssrn.com/abstract=3804353 or https://dx.doi.org/10.2139/ssrn.3804353, http://dx.doi.org/10.2139/ssrn.3804353

Izoulet, M. (2021). An Accounting History of Credit Money. Available at SSRN: https://ssrn.com/abstract=3803766 or https://dx.doi.org/10.2139/ssrn.3803766, http://dx.doi.org/10.2139/ssrn.3803766

Izoulet, M. (2020). Théorie comptable de la monnaie et de la finance, Paris, EHESS, available at Theses.fr : http:// www.theses.fr/2020EHES0110

Munidewi, I.A.B. (2018). Accounting in Reality (AIR) as a Deterrent of Accounting Practices Commonness, The $9^{\text {th }}$ International Conference Rural Research \& Planning Group, 95-101.

Pasek, A. (2019). Fixing Carbon: Mediating Matter in a Warming World, New York University, ProQuest Dissertations Publishing 13901005.

Sangster, A. (2015). The genesis of double entry bookkeeping. The Accounting Review, http://dx.doi.org/10.2308/accr51115 (in press).

Soll, J. (2015). The Reckoning, Financial Accountability and the Making and Breaking of Nations, Penguin Books.

Treapat, L.M. and Gheorghiu, A. (2015). The Story of CHF or How to Lose Your Sleep and Money by Ignoring the Foreign Currency Risk. In Proceedings of the International Conference „Risk in Contemporary Economy. Dunarea de Jos University of Galati. Romania, Faculty of Economics and Business Administration. Retrieved from http:// www.rce.feaa.ugal.ro/index.php/2014-02-04-19-50-49/rec2015.

Warsono, S. (2015). The Rationality of Rules of Debit and Credit. Available at SSRN: https://ssrn.com/abstract=2699053 or https://dx.doi.org/10.2139/ssrn.2699053, http://dx.doi.org/10.2139/ssrn.2699053

Wang, J.J. and Cortese, C. (2021). Tracing dual entry beyond the Eurocentric boundary, Accounting \& Finance.

Wang, Jing., Zhao, L. and Hooper, Keith, (2017). Is emergence sufficient to explain the origins of Double Entry?. Faculty of Business - Papers (Archive). 1732. https://ro.uow.edu.au/buspapers/1732

Cite this article as: Maxime Izoulet (2021). The accounting nature of money and claims. International Journal of M anagement Research and Economics. 1(2), 10-17. doi: 10.51483/ IJ M RE.1.2.2021. 10-17. 